Ann. rheum. Dis. (1968), 27, 431

\title{
SERUM LEVELS OF IgG, IgM, and IgA IN RHEUMATOID ARTHRITIS
}

\author{
BY \\ E. M. VEYS AND H. E. CLAESSENS \\ From the Department of Physical Medicine and Orthopaedic Surgery \\ (Director: Prof. Dr. H. Claessens) and the \\ Department of Protein Chemistry (Director: Prof. Dr. R. Wieme), \\ University of Ghent, Belgium
}

The role of immunoglobulins in the pathogenesis of rheumatoid arthritis (RA) has been studied by Franklin and Kunkel (1957), Hamerman (1966), and Hollander, McCarty, Astorga, and CastroMurillo (1965). The inconstancy of the reported presence of the rheumatoid factor (RF), which is considered by Franklin and Kunkel to be a complex composed of altered IgG bound to a molecule of IgM, and also the variability of serum levels of gamma globulins as determined by simple or immuno-electrophoresis has led us to study these levels by more specific analytical procedures.

We have compared the levels of IgG, IgM, and IgA by quantitative immunoprecipitation according to the method of Mancini, Vaerman, Carbonara, and Heremans (1964), modified by Fahey and McKelvey (1965), and have related the results to the clinical stage, the duration of disease, the rheumatoid factor titre, and the patient's age.

\section{Materials and Methods}

The sera of 71 patients with typical RA (ARA criteria: Ropes, Bennett, Cobb, Jacox, and Jessar, 1959), and of 35 normal individuals were examined. The stage of disease was graded in accordance with the method of Steinbrocker, Traeger, and Batterman (1949). There were twenty cases in Stage I, seventeen in Stage II, eighteen in Stage III, and sixteen in Stage IV.

The age distribution of the patients and normal subjects is given in Table I; we were not able to include many normal individuals over 60 years of age.

TABLE I

DISTRIBUTION OF PATIENTS AND CONTROLS ACCORDING TO AGE GROUP

\begin{tabular}{c|c|c}
\hline $\begin{array}{c}\text { Age Group } \\
\text { (yrs) }\end{array}$ & Rheumatoid Arthritis & Normal \\
\hline $21-40$ & 11 & \\
$41-60$ & 39 & 28 \\
$61-80$ & 21 & 7 \\
\hline Total & 71 & 35 \\
\hline
\end{tabular}

* For this work immunoplates (B) supplied by Hyland Laboratories were used.
The rheumatoid factor (RF) titre was determined by the following tests as described by Veys and Claessens (1966):

(1) Sensitized human cell agglutination test (SHCT),

(2) Svartz and Schlossmann (1955) cold precipitate test;

Serum accepted as positive if agglutination to a titre of 1/32 or more is observed for Tests 1 and 2 .

(3) F II latex-fixation test;

(4) Latex cold precipitate test (LCPT).

Serum accepted as positive if agglutination to a titre of $1 / 160$ or more is observed for Tests 3 and 4.

The serum Ig levels were assayed by the single radial immunodiffusion method* of Mancini and others (1964). In this diffusion technique the antibody antiserum against IgG, $M$ or $A$ is already incorporated in an agar gel layer resting on the bottom half of a plastic box. Wells of a specified diameter are punched out and filled with the sample to be examined $(10 \mu \mathrm{l}$.) by means of a semiautomatic (Kreutzer, 1963) micropipette. On each plate the first three wells are filled with different standard sera with a known concentration of the specified globulin. The remaining cups are filled with the samples to be examined. The box is closed, sealed by dipping into fluid paraffin, and incubated at room temperature $\left(20-25^{\circ} \mathrm{C}\right.$.) for 16 hours for $\operatorname{IgA}$ and $\operatorname{IgM}$, and at $37^{\circ} \mathrm{C}$. for 4 hours for IgG.

The diameters of the precipitation rings are then measured by placing the plates under a binocular magnifying glass graduated in $0.1 \mathrm{~mm}$. The values obtained for the standard solutions are plotted on semilog. paper with concentration on the linear scale. A standard curve is thus obtained for calculation of the $\mathbf{~ I g}$ levels of all samples analysed in the same series.

Since free migration of IgM in an agar gel is often checked (Wieme, 1960, 1965), we also determined the IgM levels after mild reductive cleavage which, as a rule, yields freely migrating units which still react with the antiserum. We used Cleland's reagent (dithiotreitol) at a concentration of $5 \cdot 3 \mathrm{mM}$. for cleaving IgM without splitting IgA and IgG. By this means the IgM precipitation line, which is very narrow and remains close to the application well when untreated serum is used, appears more like the IgG and IgA lines and also migrates further into the gel. 


\section{Results}

The accuracy of the method was analysed by daily determination for 10 days of the IgG, IgM, and $\operatorname{IgA}$ levels of three different samples. The results are given in Table II.

TABLE II

SERUM Ig LEVELS BY THE MANCINI METHOD MEASURED IN THE COURSE OF 10 DAYS (mg. per cent.)

\begin{tabular}{|c|c|c|c|}
\hline Ig Type & $\begin{array}{c}\text { Mean } \\
\text { (mg. per cent.) }\end{array}$ & $\begin{array}{l}\text { Standard } \\
\text { Deviation }\end{array}$ & $\begin{array}{c}\text { Coefficient of } \\
\text { Variation (per cent.) }\end{array}$ \\
\hline \multirow{3}{*}{ IgG } & 795 & 75 & $9 \cdot 4$ \\
\hline & 1,320 & 61 & $4 \cdot 6$ \\
\hline & 1,450 & 85 & 6 \\
\hline \multirow{3}{*}{ IgM } & 51 & 11 & 22 \\
\hline & 85 & 4 & 5 \\
\hline & 114 & $6 \cdot 5$ & $5 \cdot 7$ \\
\hline \multirow{3}{*}{ IgA } & 211 & 13 & 6 \\
\hline & 330 & $10 \cdot 7$ & $3 \cdot 3$ \\
\hline & 438 & 17 & 4 \\
\hline
\end{tabular}

In normal subjects, IgG levels ranged from 400 to $2000 \mathrm{mg}$. per cent., IgM from 30 to $170 \mathrm{mg}$. per cent., and IgA from 50 to $400 \mathrm{mg}$. per cent. (Fig. 1, opposite).

In patients with RA the range for IgG was 700 to $2500 \mathrm{mg}$. per cent., for IgM 20 to $220 \mathrm{mg}$. per cent., and for IgA 150 to $125 \mathrm{mg}$. per cent. (Fig. 1, opposite).

The means are shown in Table III (opposite).

We were surprised to find this wide range of variation which, of course, interferes with the delineation of groups. This difficulty remained when the subjects were classified by stage of disease (Table IV, and Fig. 1, opposite), or by age, duration of disease, and RF titre (Tables V to VII and Figs 2 to 4 , overleaf).

Table VIII shows the IgM levels after reduction $\vec{\circ}$ of the serum sample; the range of variation remained as large as with untreated samples.

\section{Discussion}

\section{Normal Values}

The normal values for the IgG and IgA levels agree with those reported in the literature and obtained by the same single radial diffusion method. Only 을 Barden, Mullinax, and Waller (1967) found higher values for IgA (mean $480 \mathrm{mg}$. per cent.).

On the other hand our mean IgM levels are lower than the $123 \mathrm{mg}$. per cent. reported by Fahey and McKelvey (1966), the $119 \mathrm{mg}$. per cent by Marcolongo, Carcassi, Frullini, Bianco, and Bravi (1967) and the $230 \mathrm{mg}$. per cent. by Barden and othere (1967). Our values correspond better with olde

TABLE IV

SERUM IMMUNOGLOBULIN LEVELS RELATED TO STAGE OF DISEASE

\begin{tabular}{|c|c|c|c|c|c|}
\hline Immunoglobulin & Stage of Disease & No. of Cases & Mean (mg. per cent.) & S.D. & S.E. of the Mean \\
\hline \multirow{5}{*}{ IgG } & $\mathbf{I}$ & 20 & 1,280 & 350 & $78 \cdot 3$ \\
\hline & II & 17 & 1,606 & 400 & $97 \cdot 0$ \\
\hline & III & 18 & 1,450 & 530 & $125 \cdot 0$ \\
\hline & IV & 16 & 1,306 & 490 & $122 \cdot 0$ \\
\hline & Total & 71 & 1,379 & 470 & $55 \cdot 7$ \\
\hline \multirow{5}{*}{ IgM } & I & 20 & 93 & 46 & $10 \cdot 3$ \\
\hline & II & 17 & 95 & 36 & $8 \cdot 7$ \\
\hline & III & 18 & 105 & 38 & $8 \cdot 9$ \\
\hline & IV & 16 & 103 & 29 & $7 \cdot 2$ \\
\hline & Total & 71 & 99 & 38 & $4 \cdot 5$ \\
\hline \multirow{5}{*}{$\operatorname{IgA}$} & I & 20 & 257 & 170 & $38 \cdot 0$ \\
\hline & II & 17 & 295 & 180 & $43 \cdot 7$ \\
\hline & III & 18 & 340 & 220 & $51 \cdot 8$ \\
\hline & IV & 16 & 409 & 300 & $75 \cdot 0$ \\
\hline & Total & 71 & 329 & 225 & $26 \cdot 7$ \\
\hline \multirow{5}{*}{ Total Ig } & I & 20 & 1,545 & 420 & $93 \cdot 9$ \\
\hline & II & 17 & 1,997 & 504 & $112 \cdot 7$ \\
\hline & III & 18 & 1,833 & 543 & $128 \cdot 0$ \\
\hline & IV & 16 & 1,809 & 609 & $152 \cdot 0$ \\
\hline & Total & 71 & 1,787 & 534 & $64 \cdot 4$ \\
\hline
\end{tabular}



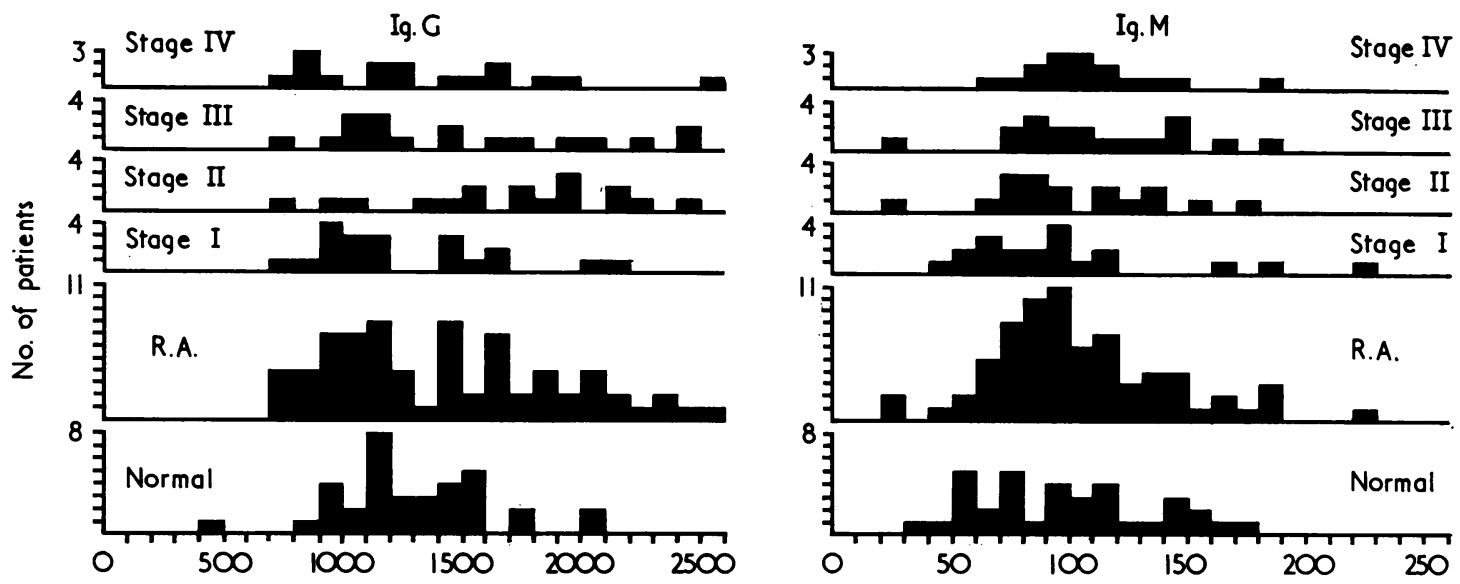
mg. per cent.

mg. per cent.

Ig. A

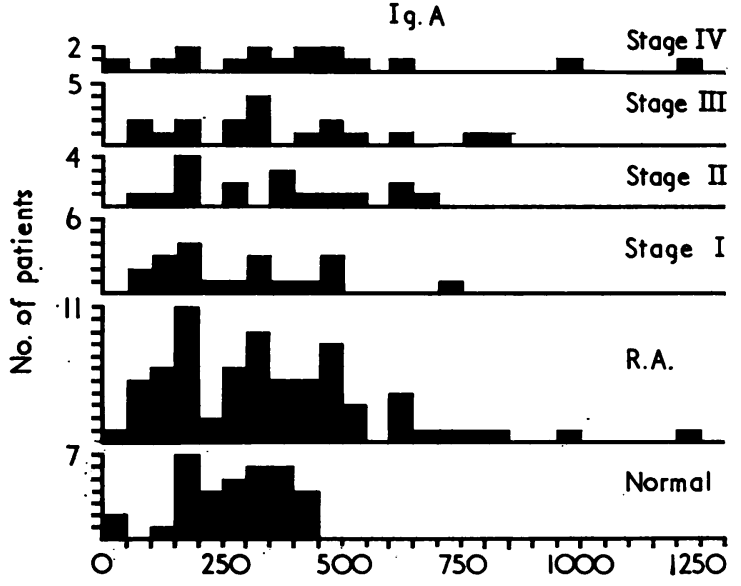

mg. per cent.

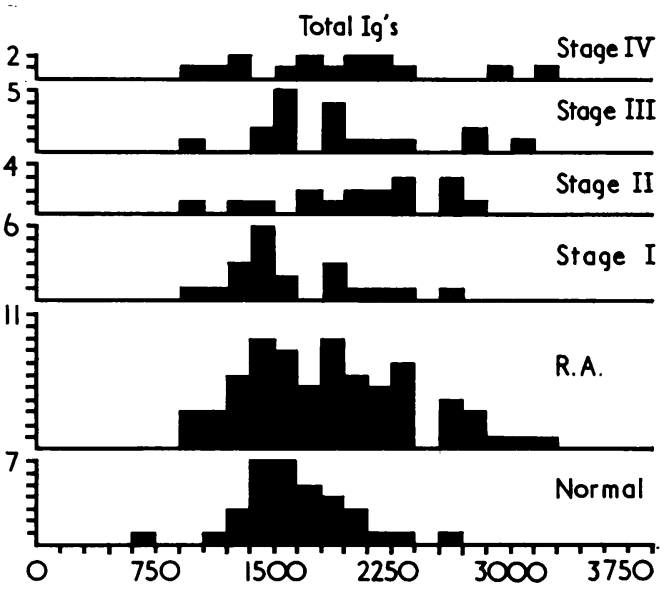

mg. per cent.

Fig. 1.-Ig levels in normal subjects and in rheumatoid arthritics, by stage of disease.

TABLE III

MEAN SERUM Ig LEVELS (mg. per cent.) IN ARTHRITIC PATIENTS AND NORMAL SUBJECTS

\begin{tabular}{|c|c|c|c|c|c|c|}
\hline Ig Type & Series & No. of Cases & Mean (mg. per cent.) & S.D. & S.E. of the Mean & $\mathbf{P}$ \\
\hline \multirow{2}{*}{ IgG } & RA & 71 & 1,380 & 470 & $55 \cdot 7$ & \multirow{2}{*}{$0.05<P<0.10$} \\
\hline & Normal & 34 & 1,250 & 300 & $51 \cdot 4$ & \\
\hline \multirow{2}{*}{ IgM } & $\mathbf{R A}$ & 71 & 99 & 38 & $4 \cdot 5$ & \multirow{2}{*}{$0.40<\mathrm{P}<0.45$} \\
\hline & Normal & 35 & 92 & 37 & $6 \cdot 2$ & \\
\hline \multirow{2}{*}{ IgA } & RA & 71 & 330 & 225 & $26 \cdot 7$ & \multirow{2}{*}{$0.025<P<0.05$} \\
\hline & Normal & 35 & 250 & 105 & $17 \cdot 7$ & \\
\hline \multirow{2}{*}{ Total Ig } & RA & 71 & 1,790 & 535 & $64 \cdot 4$ & \multirow{2}{*}{$0.0125<P<0.025$} \\
\hline & Normal & 34 & 1,570 & 360 & $61 \cdot 7$ & \\
\hline
\end{tabular}


TABLE V

SERUM IMMUNOGLOBULIN LEVELS RELATED TO AGE (YRS)

\begin{tabular}{|c|c|c|c|c|c|c|}
\hline Immunoglobulin & Age (yrs) & Series & No. of Cases & Mean (mg. per cent.) & S.D. & S.E. of the Mean \\
\hline \multirow{6}{*}{ IgG } & \multirow{2}{*}{$21-40$} & RA & 11 & 1,145 & 534 & $160 \cdot 8$ \\
\hline & & Normal & 27 & 1,218 & 296 & 56.9 \\
\hline & \multirow{2}{*}{$41-60$} & RA & 39 & 1,461 & 463 & $73 \cdot 0$ \\
\hline & & Normal & 7 & 1,400 & 424 & $160 \cdot 0$ \\
\hline & \multirow{2}{*}{$61-80$} & $\mathbf{R A}$ & 21 & 1,410 & 400 & $87 \cdot 3$ \\
\hline & & Normal & 0 & Not determined & & \\
\hline \multirow{6}{*}{ IgM } & \multirow{2}{*}{$21-40$} & RA & 11 & 95 & 40 & $12 \cdot 0$ \\
\hline & & Normal & 28 & 96 & 36 & 6.9 \\
\hline & \multirow{2}{*}{$41-60$} & $\mathbf{R A}$ & 39 & 103 & 37 & $5 \cdot 9$ \\
\hline & & Normal & 7 & 84 & 44 & $16 \cdot 6$ \\
\hline & \multirow{2}{*}{$61-80$} & RA & 21 & 95 & 39 & $8 \cdot 5$ \\
\hline & & Normal & 0 & Not determined & & \\
\hline \multirow{6}{*}{$\operatorname{IgA}$} & \multirow{2}{*}{$21-40$} & RA & 11 & 145 & 118 & $35 \cdot 5$ \\
\hline & & Normal & 28 & 239 & 115 & $22 \cdot 1$ \\
\hline & \multirow{2}{*}{$41-60$} & RA & 39 & 325 & 183 & $29 \cdot 3$ \\
\hline & & Normal & 7 & 286 & 54 & $20 \cdot 4$ \\
\hline & \multirow{2}{*}{$61-80$} & $\mathbf{R A}$ & 21 & 433 & 280 & $61 \cdot 1$ \\
\hline & & Normal & 0 & Not determined & & \\
\hline \multirow{6}{*}{ Total Ig } & \multirow{2}{*}{$21-40$} & RA & 11 & 1,275 & 280 & $84 \cdot 3$ \\
\hline & & Normal & 27 & 1,500 & 335 & $64 \cdot 4$ \\
\hline & \multirow{2}{*}{$41-60$} & $\mathbf{R A}$ & 39 & 1,869 & 481 & $75 \cdot 9$ \\
\hline & & Normal & 7 & 1,779 & 420 & $156 \cdot 6$ \\
\hline & \multirow{2}{*}{$61-80$} & RA & 21 & 1,886 & 585 & $127 \cdot 5$ \\
\hline & & Normal & 0 & Not determined & & \\
\hline
\end{tabular}

measurements obtained by quantitative immunoprecipitation (Franklin and Kunkel, 1957) and by precipitation in Oudin tubes (Heremans, 1960). They also fit the values reported by Schultze and Heremans (1966), a range of 39 to $117 \mathrm{mg}$. per cent. (mean 75 mg. per cent.).

This discrepancy raises the question whether the single radial diffusion method is adequate in determining IgM levels. The migration of these large molecules into an agar gel may be hindered either by a molecular sieve effect or by chemical interaction. Mild reduction checks this type of interaction, and might be expected to improve the quantitative response. However, we did not find a marked narrowing of the range upon reduction. We only noted a marked shift in the mean normal value (from 92 to $159 \mathrm{mg}$. per cent.) with a parallel increase in the pathological values. Apparently, the reference sera did not respond to reduction as well as the sera under investigation.

The difference between the levels of IgA obtained by the different methods may be due in part to the variations in molecular size of these immunoglobulins which occur as a rather ill-defined polymeric series. For this reason it is necessary to know the polymeric constitution as well as for the exact concentration of the reference sera. If the unknown sample is more polymerized than the reference serum, one expects too low a value using diffusion methods. This also explains the higher values obtained by Fahey and McKelvey (1965) by the isotopic immune inhibition method. It must be remembered that the concentration values estimated here depend on the figure attributed to the reference sera and on their qualitative similarity to the sample to be analysed. 
TABLE VI

SERUM IMMUNOGLOBULIN LEVELS RELATED TO DURATION OF DISEASE (YRS)

\begin{tabular}{|c|c|c|c|c|c|}
\hline Immunoglobulin & $\begin{array}{c}\text { Duration of Disease } \\
\text { (yrs) }\end{array}$ & $\begin{array}{l}\text { No. of } \\
\text { Cases }\end{array}$ & Mean (mg. per cent.) & S.D. & S.E. of the Mean \\
\hline \multirow{5}{*}{ IgG } & $0-5$ & 31 & 1,313 & 464 & $82 \cdot 7$ \\
\hline & $6-10$ & 15 & 1,447 & 450 & $116 \cdot 2$ \\
\hline & $11-15$ & 9 & 1,490 & 500 & $166 \cdot 6$ \\
\hline & $16-20$ & 6 & 1,567 & 663 & $270 \cdot 6$ \\
\hline & $>20$ & 10 & 1,280 & 400 & $126 \cdot 5$ \\
\hline \multirow{5}{*}{ IgM } & $0-5$ & 31 & 97 & 42 & $7 \cdot 7$ \\
\hline & $6-10$ & 15 & 93 & 40 & $10 \cdot 3$ \\
\hline & $11-15$ & 9 & 105 & 37 & $12 \cdot 3$ \\
\hline & $16-20$ & 6 & 105 & 38 & $15 \cdot 5$ \\
\hline & $>20$ & 10 & 107 & 20 & $6 \cdot 3$ \\
\hline \multirow{5}{*}{$\operatorname{IgA}$} & $0-5$ & 31 & 260 & 169 & $30 \cdot 3$ \\
\hline & $6-10$ & 15 & 363 & 275 & $71 \cdot 0$ \\
\hline & $11-15$ & 9 & 333 & 105 & $35 \cdot 0$ \\
\hline & $16-20$ & 6 & 292 & 137 & $55 \cdot 9$ \\
\hline & $>20$ & 10 & 520 & 300 & $94 \cdot 9$ \\
\hline \multirow{5}{*}{ Total Ig } & $0-5$ & 31 & 1,655 & 500 & $89 \cdot 7$ \\
\hline & $6-10$ & 15 & 1,820 & 525 & $135 \cdot 6$ \\
\hline & $11-15$ & 9 & 1,917 & 500 & $166 \cdot 6$ \\
\hline & $16-20$ & 6 & 1,920 & 580 & $236 \cdot 7$ \\
\hline & $>20$ & 10 & 1,920 & 580 & $183 \cdot 5$ \\
\hline
\end{tabular}

\section{Comparison between Normal Subjects and Patients with RA}

30 per cent. of the patients with RA have normal immunoglobulin levels, so that the Ig levels are of small diagnostic value.

We did not find statistically significant differences between the IgM levels in normal subjects and in arthritic patients, but the mean IgG, IgA, and total Ig levels were markedly raised in the arthritic patients. These results substantiate the observations of Heremans (1960) and Marcolongo and others (1967), but are opposed to those of Claman and Merrill (1966) and of Barden and others (1967).

Simple immuno-electrophoretic analysis in patients with RA (Podliachouk, Francq, Eyquem, and Jacqueline, 1960; Eyquem, Jacqueline, Podliachouk, and Francq, 1960) has shown an inconstant accentuation of the precipitation line corresponding to the IgM fraction, but Heremans and several other authors reported the increase in IgM to be a constant finding. It is remarkable, however, that Heremans could not reproduce this increase by the Oudin tube method, and reported that in some cases there was no precipitate at all. It appears to us, in agreement with Heremans (1960), that much of the IgM is engaged in the RF (IgM-IgG) complex (Franklin, Edelman, and Kunkel, 1959) and cannot be determined by the usual methods.

We found a marked increase in the IgA levels in patients with RA. This suggests some pathogenetic relationship between the IgA and RA. According to Merler and Rosen (1966), Alper, Rosen, and Janeway (1966), and Janeway and Rosen (1966), the rheumatoid factor should also be able to combine with $\operatorname{IgA}$, but the influence of increasing age has also to be taken into consideration.

The mean values for IgG and for total Ig are markedly increased in patients with RA. This increase seems to be related, in the first place, to an increased production. Sell and Fahey (1964) demonstrated that Ig synthesis increases and serum levels rise after the exposure of germ-free animals to a normal, non-sterile environment. An increase in serum IgG is usual in cases of infection. It is thus tempting to postulate the presence of a constant antigenic stimulation in cases of RA, but we have also to be aware of the similarity of these results to those obtained in other collagen diseases and in haemolytic anaemia, where the source of increased IgG is less obvious. 
Immunoglobulin Levels related to Stage of Disease (see Table IV, p. 432, and Fig. 1, p. 433).

We did not find any statistically significant difference between the IgM levels in the four disease stages. But the mean IgG levels, which seem normal in Stage I, increase markedly in Stages II and III, and tend to return to normal in Stage IV.

It is generally accepted that the disease tends to stabilize in Stage IV. This may seem true for some biological landmarks, such as the RF titre, but important tissue destruction does still occur. We therefore think that in Stage IV the IgG is consumed at the sites of tissue destruction (Hollander, 1966). This could lead to a decrease of the serum level if immunoglobulin synthesis does not follow.

The mean IgA levels increase progressively with disease stage, and there is a statistically significant difference between Stages I and III and Stages II and IV. We have no explanation for these observations, but the age factor may have some importance.

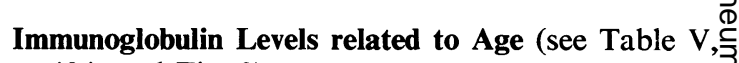
p. 434, and Fig. 2).

There is a significant increase in IgG and in the total Ig levels in normal subjects between the ages of 40 and 60 . We also found higher values for $\operatorname{IgA}$ in this group, but this was not statistically significant.등 We were unable to examine serum samples of normal $\overline{\frac{\bar{p}}{}}$. subjects over 60 years of age.

In patients with RA we observed a similar trend, but in those over 60 years old the IgG levels werenormal. Many of these patients were in Stage IV? The IgA levels were found to increase with age and $\vec{\omega}$ here the difference was statistically significant. Weo found no differences between the IgM levels.

It should be noted that we failed to find a differ ence between the mean levels of IgG, IgM, and $\operatorname{IgA}$ ir in patients with RA and normal subjects of same agect group. It thus seems essential to compare the $\mathrm{Ig}_{\mathrm{O}}$ levels in individuals of the same age.

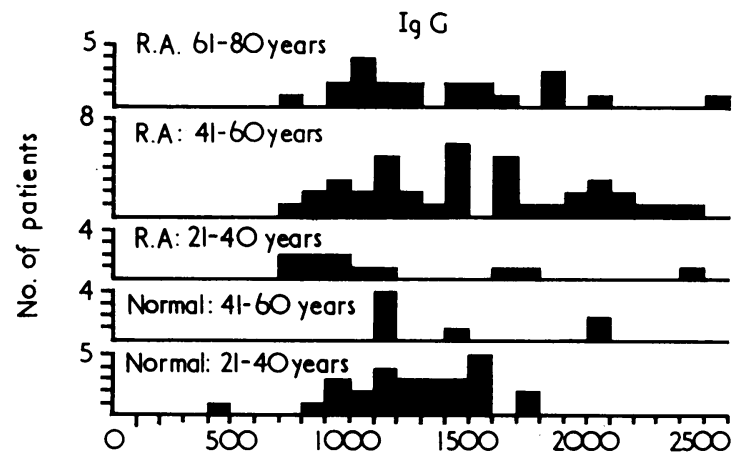

mg. per cent.

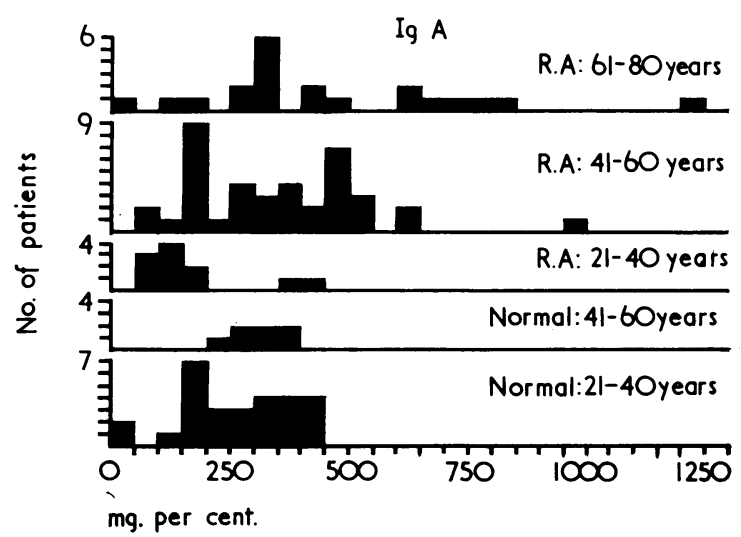

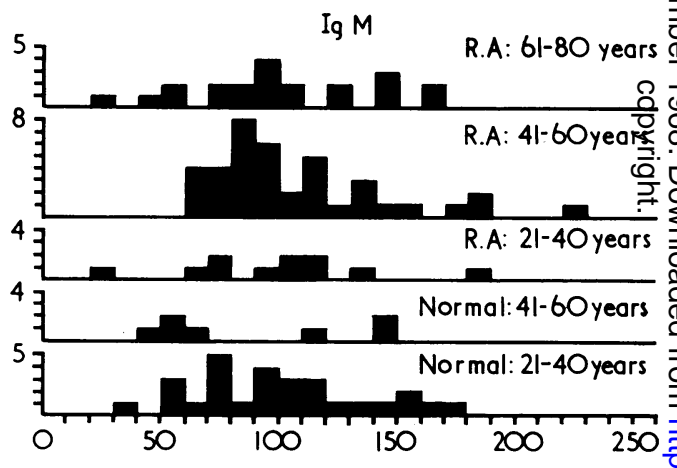

mg. per cent.

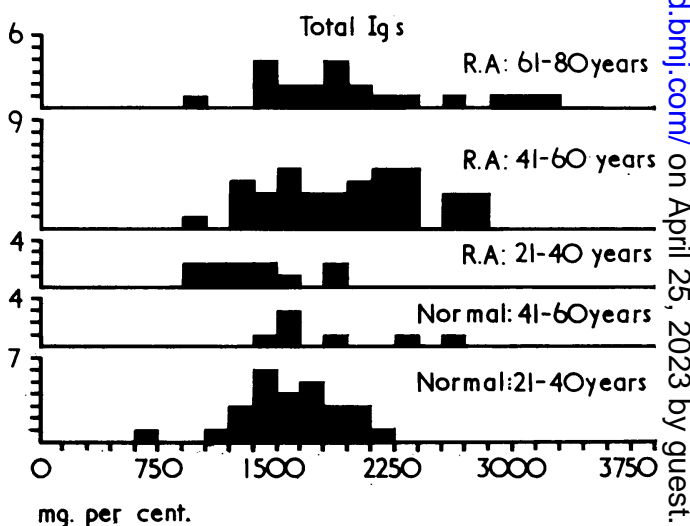

mg. per cent.

Fig. 2.-Ig levels in arthritics and normal subjects, by age. 


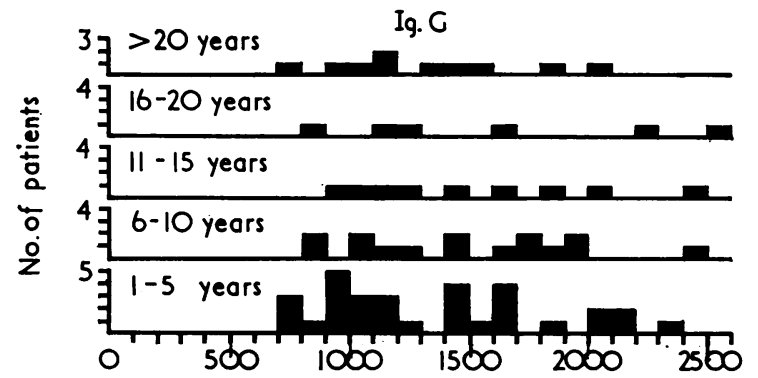

mg. per cent.

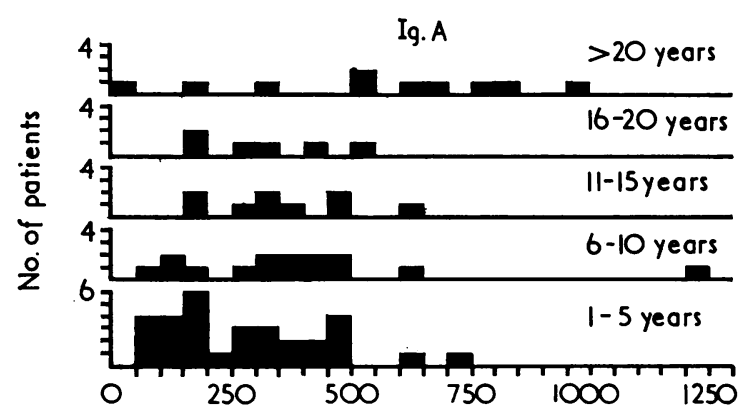

mg. per cent.

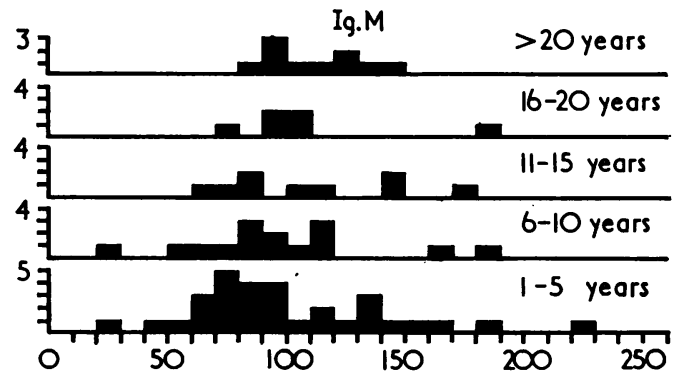

mg. per cent.

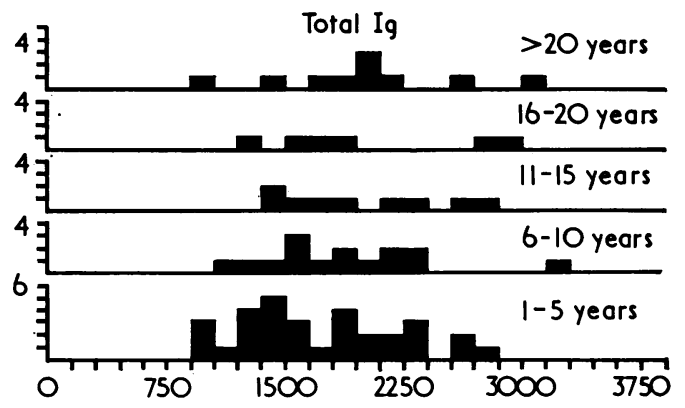

mg. per cent

Fig. 3.-Ig levels in arthritics, by duration of disease.

Immunoglobulin Levels related to Duration of Disease (see Table VI, p. 435, and Fig. 3).

Here the results are similar to those in patients grouped by stage of disease. The IgG, IgA, and total Ig levels increased with duration of disease.

In patients with a duration of disease of more than 20 years (this group includes many patients in Stage IV), the IgG levels were markedly lower than those who had had the disease for less than 20 years.

Immunoglobulin Levels related to RF Titre (see Table VII and Fig. 4, overleaf).

The serum levels of $\operatorname{IgG}, \operatorname{IgM}$, and $\operatorname{IgA}$ as well as the total Ig are increased in sero-positive cases tested by the SHCT. The levels of IgA, IgM, and total Ig are increased in sero-positive cases tested by the LCPT. We did not find a strict quantitative relationship between any of the Ig levels and the RF titre; this is to be expected considering that the serological tests are semi-quantitative methods.

It is easy to explain the increase of the IgG and IgM levels in sero-positive cases, when the association of the rheumatoid factor with IgM and IgG is considered. The increase in IgA levels fits the hypothesis of Heremans and Vaerman (1962) and of
Alper and others (1966), according to whom the rheumatoid factor is in some cases associated with the IgA fraction.

\section{Summary}

The serum IgG, IgM, and IgA levels were determined in 71 patients with rheumatoid arthritis and in 35 normal individuals by the single radial diffusion method of Mancini and others (1964). These levels were compared with the stage of disease, age, duration of disease, and RF titre.

The comparison between the age groups proved to be especially interesting; it appears that specific changes in immunoglobulins can be compared only in comparable age groups.

The mean IgM levels were found to be normal in patients with rheumatoid arthritis.

The mean IgG levels in cases of Stage IV disease were lower than those in Stage III.

When the serum was positive for rheumatoid factor, the levels of IgG and of IgM tended to be raised, which seems to accord with the nature of the rheumatoid factor; there was also an increase in IgA levels. 

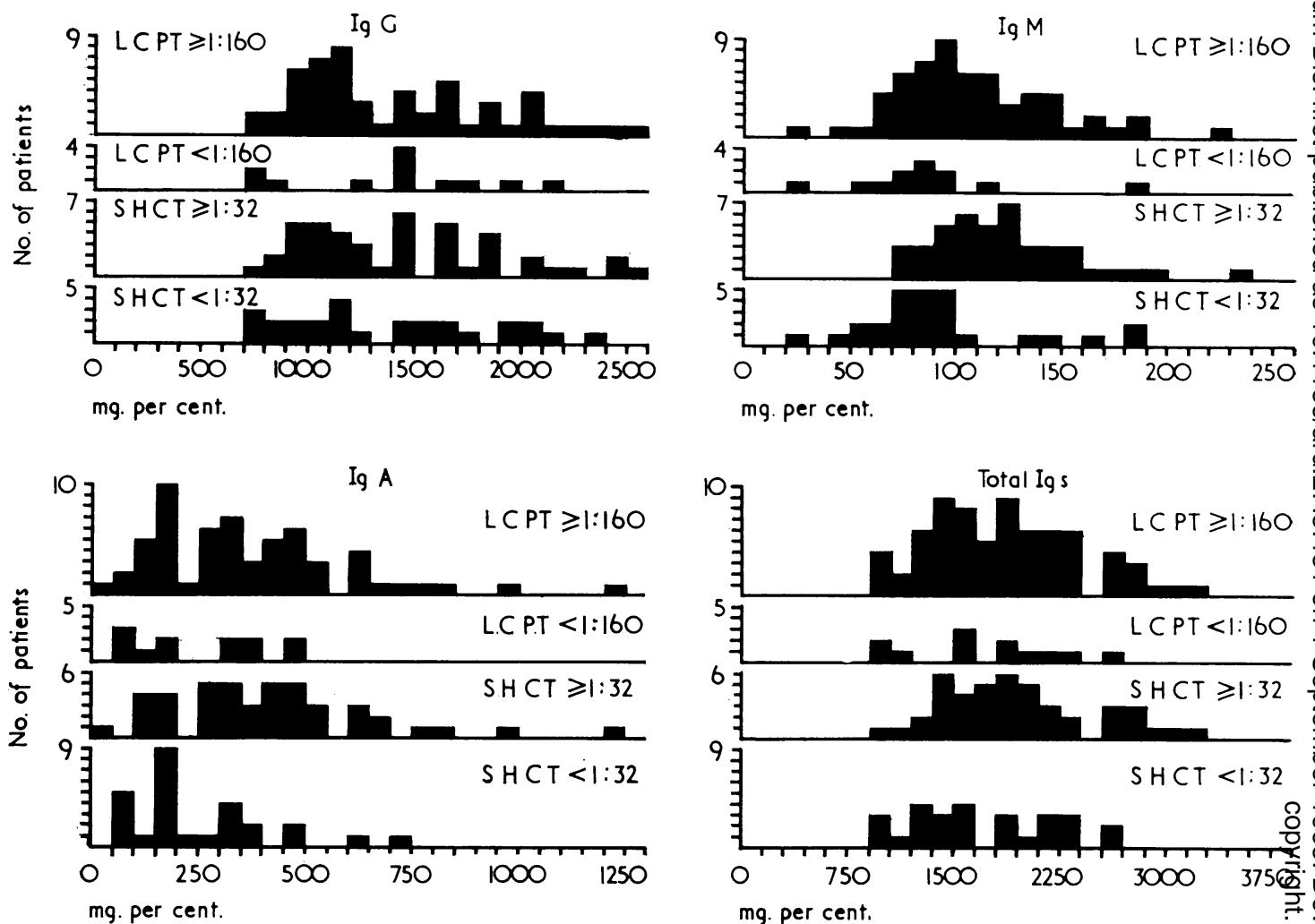

Fig. 4.- Ig levels in sero-positive and sero-negative arthritics tested by the sensitized human cell test and the latex cold precipitate test.

TABLE VII

SERUM IMMUNOGLOBULINS IN SERO-POSITIVE AND SERO-NEGATIVE CASES OF RA

\begin{tabular}{|c|c|c|c|c|c|c|}
\hline Immunoglobulin & RF Titre & $\begin{array}{l}\text { No. of } \\
\text { Cases }\end{array}$ & Mean (mg. per cent.) & S.D. & $\begin{array}{l}\text { S.E. of the } \\
\text { Mean }\end{array}$ & $\mathbf{P}$ \\
\hline \multirow{4}{*}{$\mathrm{IgG}$} & \multirow{2}{*}{ SHCT $\begin{array}{l}1 / 32 \\
1 / 32\end{array}$} & 27 & 1.335 & 480 & $92 \cdot 3$ & \multirow{2}{*}{$0 \cdot 05<P<0 \cdot 10$} \\
\hline & & 44 & 1.536 & 545 & $82 \cdot 1$ & \\
\hline & \multirow{2}{*}{$\begin{array}{ll}\text { LCPT } & 1 / 160 \\
& =1 / 160\end{array}$} & 12 & 1,358 & 450 & $130 \cdot 0$ & \multirow{2}{*}{$0.40 \cdot P \cdot 0.45$} \\
\hline & & 59 & 1,382 & 450 & $59 \cdot 0$ & \\
\hline \multirow{4}{*}{$\operatorname{IgM}$} & \multirow{2}{*}{$\begin{array}{ll} & 1 / 32 \\
\text { SHCT } & 1 / 32\end{array}$} & 27 & 84 & 35 & $6 \cdot 7$ & \multirow{2}{*}{$0,0005 \quad P \quad 0.0025$} \\
\hline & & 44 & 108 & 35 & $5 \cdot 2$ & \\
\hline & \multirow{2}{*}{$\begin{array}{lll} & 1 / 160 \\
\text { LCPT } & 1 / 160\end{array}$} & 12 & 82 & 38 & $10 \cdot 9$ & \multirow{2}{*}{$0 \cdot 025 \cdot P \cdot 0 \cdot 05$} \\
\hline & & 59 & 102 & 38 & $4 \cdot 9$ & \\
\hline \multirow{4}{*}{$\lg \mathrm{A}$} & \multirow{2}{*}{$\begin{array}{ll}\text { SHCT } & 1 / 32 \\
-1 & 32\end{array}$} & 27 & 232 & 160 & $30 \cdot 8$ & \multirow{2}{*}{$0.0005 \cdot P \cdot 0.0025$} \\
\hline & & 44 & 394 & 232 & $34 \cdot 9$ & \\
\hline & \multirow{2}{*}{$\begin{array}{lll}\text { LCPT } & 1 / 160 \\
& 1160\end{array}$} & 12 & 229 & 150 & $43 \cdot 3$ & \multirow{2}{*}{$0.025 . \quad P<0.05$} \\
\hline & & 59 & 344 & 223 & $29 \cdot 2$ & \\
\hline \multirow{4}{*}{ Total Ig } & \multirow{2}{*}{$\begin{array}{ll} & 1 / 32 \\
\text { SHCT } & 1 / 32\end{array}$} & 27 & 1,633 & 410 & $78 \cdot 9$ & \multirow{2}{*}{$0.0125<\mathbf{P}<0.025$} \\
\hline & & 44 & 1,880 & 543 & $81 \cdot 9$ & \\
\hline & \multirow{2}{*}{$\begin{array}{ll}1 / 160 \\
\text { LCPT }\end{array}$} & 12 & 1,650 & 525 & $151 \cdot 7$ & \multirow{2}{*}{$0 \cdot 20<P<0 \cdot 25$} \\
\hline & & 59 & 1,780 & 588 & $77 \cdot 1$ & \\
\hline
\end{tabular}


TABLE VIII

IgM LEVELS IN SERUM AND REDUCED SERUM

\begin{tabular}{|c|c|c|c|c|c|c|}
\hline Ig $\mathbf{M}$ & Series & No. of Cases & Mean (mg. per cent.) & S.D. & S.E. of the Mean & $\mathbf{P}$ \\
\hline \multirow{2}{*}{ Not Reduced } & Normal & 35 & 92 & 37 & $6 \cdot 2$ & \multirow{2}{*}{$0.40<P<0.45$} \\
\hline & $\mathbf{R A}$ & 71 & 99 & 38 & $4 \cdot 5$ & \\
\hline \multirow{2}{*}{ Reduced } & Normal & 14 & 159 & 70 & . $18 \cdot 7$ & \multirow{2}{*}{$0.40<P<0.45$} \\
\hline & RA & 25 & 162 & 54 & $10 \cdot 8$ & \\
\hline
\end{tabular}

\section{REFERENCES}

Alper, C. A., Rosen, F. S., and Janeway, C. A. (1966). New Engl. J. Med., 275, 591 (The gamma globulins, II, Hypergammaglobulinemia).

Barden, J., Mullinax, F., and Waller, M. (1967). Arthr. and Rheum., 10, 228 (Immunoglobulin levels in rheumatoid arthritis).

Claman, H. N., and Merrill, D. (1966). J. Lab. clin. Med., 67, 850 (Serum immunoglobulins in rheumatoid arthritis).

Eyquem, A., Jacqueline, F., Podliachouk, L., and Francq, J. C. (1960). Rev. franç. Ét. clin. biol., 5, 58 (Problèmes immunologiques de la polyarthrite chronique évolutive).

Fahey, J. L., and McKelvey, E. M. (1965). J. Immunol., 94, 84 (Quantitative determination of serum immunoglobulins in antibody-agar plates).

Franklin, E. C., Edelman, G., and Kunkel, H. G. (1959). In "Immunity and Virus Infection; Symposium held at Vanderbilt University School of Medicine, 1958”, ed. V. A. Naijar, p. 92. Wiley, New York.

— and Kunkel, H. G. (1957). J. Immunol., 78, 11 (Immunologic differences between the 19S and $7 \mathrm{~S}$ components of normal human $\gamma$-globulin).

Hamerman, D. (1966). Amer. J. Med., 40, 1 (New thoughts on the pathogenesis of rheumatoid arthritis).

Heremans, J. F. (1960). "Les globulines sériques du système gamma". ARSCIA, Brussels.

— and Vaerman, J. P. (1962). Nature (Lond.), 193, 1091 ( $\beta 2$ A-globulin as a possible carrier of allergic reaginic activity).

Hollander, J. L. (1966). Méd. et Hyg., 24, 405 (Nouvelles découvertes sur l'immunopathogénèse en matière de polyarthrite chronique évolutive). (27 Avril, 1966.)

—, McCarty, D. J., Astorga, G., and Castro-Murillo, E. (1965). Ann. intern. Med., 62, 271 (Studies on the pathogenesis of rheumatoid joint inflammation. I. The "R.A. cell" and a working hypothesis).

Janeway, C. A., and Rosen, F. S. (1966). New Engl. J. Med., 275, 826 (The gamma globulins. IV. Therapeutic uses of gamma globulin).

Kreutzer, H. H. (1963). Clin. chim. Acta, 8, 167 (A simple pipette for the application of the sample in agar gel electrophoresis).

Mancini, G., Vaerman, J. P., Carbonara, A. O., and Heremans, J. F. (1964). In "Protides of the Biological Fluids: Proceedings of the XI Colloquium. Bruges, 1963", ed. H. Peeters, p. 370, Elsevier, Amsterdam, London, New York (A single-radial-diffusion method for the immunological quantitation of proteins).

Marcolongo, R., Jr., Carcassi, A., Frullini, F., Bianco, G., and Bravi, A. (1967). Ann. rheum. Dis., 26, 412 (Levels of serum immunoglobulins in patients with rheumatoid arthritis).

Merler, E., and Rosen, F. S. (1966). New Engl. J. Med., 275, 480 (The gamma globulins. I. The structure and synthesis of the immunoglobulins).

Podliachouk, J., Francq, J. C., Eyquem, A., and Jacqueline, F. (1960). Ann. Inst. Pasteur, 98, 90 (Antigénicité des facteurs sérologiques de la polyarthrite chronique évolutive). 
Ropes, M. W., Bennett, G. A., Cobb, S., Jacox, R., and Jessar, R. A. (1959). Ann. rheum. Dis., 18, 49 (1958 Revision: diagnostic criteria for rheumatoid arthritis).

Rosen, F. S., and Janeway, C. A. (1966). New Engl. J. Med., 275, 709 (The gamma globulins. III. The antibody deficiency syndromes).

Sell, S., and Fahey, J. L. (1964). J. Immunol., 93, 81 (Relationship between gamma globulin metabolism and low serum $\gamma$-globulin in germfree mice).

Schultze, H. E., and Heremans, J. F. (1966). "Molecular biology of Human Proteins. Vol. I: Nature and Metabolism of extra cellular proteins". Elsevier, Amsterdam, London, New York.

Steinbrocker, O., Traeger, C. H., and Batterman, R. C. (1949). J. Amer. med. Ass., 140, 659 (Therapeutic criteria in rheumatoid arthritis).

Svartz, N., and Schlossmann, K. (1955). Ann. rheum. Dis., 14, 191 (Cold precipitable haemagglutinating factor in serum from patients with rheumatoid arthritis).

Veys, E., and Claessens, H. (1966). T. Geneesk., 10, 457 (Diagnostische waarde van de reuma-tests. Vergelijkende studie op 1100 sera).

Wieme, R. J. (1960). In "Protides of the Biological Fluids: Proceedings of the VII Colloquium. Bruges, 1959", ed. H. Peeters, p. 18. Elsevier, Amsterdam, London, New York. (On some interactions occurring between agar and certain substances submitted to electrophoresis in this medium.)

__ (1965). “Agar Gel Electrophoresis". Elsevier, Amsterdam, London, New York.

Taux sériques d'immunoglobulines $G, M$ et $A$ dans la polyarthrite rhumatoïde

\section{RÉSUMÉ}

Les auteurs étudièrent les taux d'immunoglobulines $\mathbf{G}$, $M$ et $A$ dans 71 cas de polyarthrite rhumatoïde et chez 35 sujets normaux suivant la méthode de simple diffusion radiale de Mancini et col. (1964). Ils considérèrent les chiffres obtenus par rapport au stade de la maladie, l'âge, la durée de la maladie et le titre du facteur rhumatoïde. La comparaison entre groupes d'âge différent se révéla intéressante: les changements spécifiques des immunoglobulines ne peuvent être comparés qu'en fonction de l'âge.

On trouva des taux moyens d'IgM normaux chez des malades atteints de polyarthrite rhumatoïde.

Les taux moyens des immunoglobulines au stade évolutif IV de la maladie étaient plus bas qu'au stade III.

Les taux des immunoglobulines $G$ et $M$ tendent à monter chez les malades ayant une sérologie positive, ce qui pourrait s'expliquer par la nature même du facteur rhumatoïde. Les auteurs notent cependant chez ces mêmes malades une augmentation des taux d'IgA.
Cifras séricas de las inmunoglobulinas $G, M$ y $A$ en la polioartritis reumatoide

\section{SUMARIO}

Se determinaron las cifras séricas de inmunoglobinas G, M y A en 71 enfermos con poliartritis reumatoide 35 sujetos normales por el simple método de difusión radial de Mancini y col. (1964). Estas cifras fueron estudiadas en relación con el grado de la enfermedad, la edad, la duración de la enfermedad y el título del factor reumatoide.

La comparación de la edad reveló un hecho interesante: cambios específicos en las inmunoglobulinas pueden compararse sólo en función de la edad.

Las cifras medias de la inmunoglobulina $\mathbf{M}$ fueron normales en enfermos con poliartritis reumatoide.

Las cifras medias de las inmunoglobulinas en el grado IV de la enfermedad fueron más bajas que las en el grado III.

En la presencia del factor reumatoide las cifras de IgG y de IgM tendían a aumentar, lo que parece acordarse con la naturaleza de este factor; las cifras de $\operatorname{IgA}$ se veían también aumentadas. 